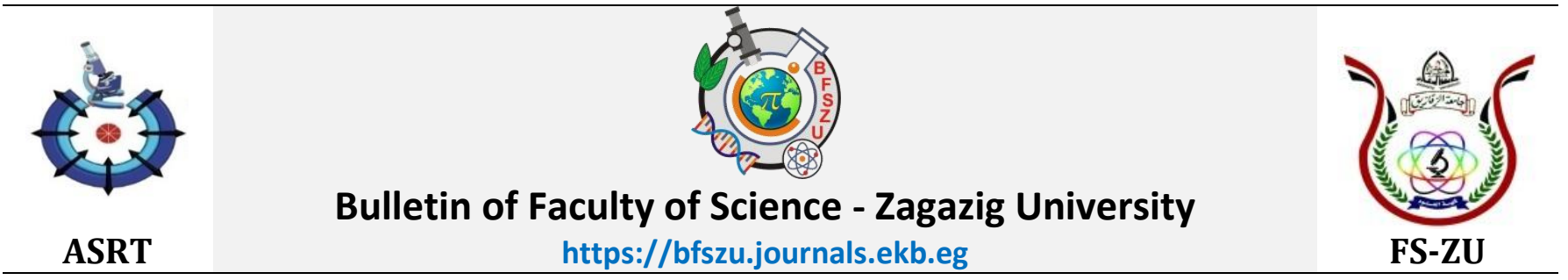

\title{
Surface active ionic liquid-assisted cloud point extraction method for preconcentration of nickel in environmental samples before its FAAS determination
}

\author{
Ragaa EI Sheikh', Eman M. Hafez ${ }^{1}$, Osama M. Salem², Saleh S. Idris ${ }^{3}$, Ibrahim S. Ali ${ }^{3,4}$, \\ Ayman A. Gouda ${ }^{1,3 *}$ \\ ${ }^{1}$ Chemistry Department, Faculty of Science, Zagazig University, Zagazig, 44519, Egypt. \\ ${ }^{2}$ Basic Science Department, Common First Year Deanship, Umm AL-Qura University, Makkah, Saudi Arabia. \\ ${ }^{3}$ Faculty of Public Health and Health Informatics, Umm AL-Qura University, Makkah, Saudi Arabia. \\ ${ }^{4}$ High Institute of Optics Technology, Cairo, Egypt.
}

\section{ARTICLE HISTORY}

Received: 29 December 2019

Revised: 11 January 2020

Accepted: 11 January 2020

Published online: July 2020

\section{KEY WORDS}

Nickel; Cloud point extraction method; Surfaceactive ionic liquid; Triton X-114; Environmental samples; FAAS.
ABSTRACT Green, rapid and modified surface-active ionic liquid assisted cloud point extraction method (SAIL-CPE) was developed to preconcentrate trace levels of nickel $\mathrm{Ni}$ (II) ions in environmental samples perior to its detection by FAAS. The proposed method based on utilizing a mixture of a nonionic surfactant (Triton X-114) and a surface-active ionic liquid, 1-hexadecyl-3-methylimidazolium chloride $\left(\mathrm{C}_{16} \mathrm{MeImCl}\right)$, as an extracting phase for $\mathrm{Ni}$ (II) ions after the complexation with sunset yellow FCF at $\mathrm{pH}$ 6.5. The impact of different analytical parameters on improving the extraction efficiency was invistigated. In the range of $2.0-600 \mu \mathrm{g} \mathrm{L}^{-1}$, the calibration graph was linear with correlation coefficient of 0.9998 . Limit of detection and preconcentration factor were 0.6 and 100. The reliability and precision of the proposed SAIL-CPE system as the relative standard deviation (RSD \%) in the presence and absence of SAIL were examined by applying ten replicate determinations of $300 \mu \mathrm{g} \mathrm{L}^{-1}$ of $\mathrm{Ni}(\mathrm{II})$, and RSD \% of the recoveries were found to be 1.40 and $2.9 \%$, respectively. The validation of the proposed procedure was verified by test of certified reference materials (TMDA-51.3 fortified water, TMDA-53.3 fortified water and SRM spinach leaves 1570A) applying the standard addition method. Finally, the proposed SAIL-CPE method was developed and applied to preconcentrate and determine of trace levels of $\mathrm{Ni}(\mathrm{II})$ ions in real water, food and tobacco samples with satisfactory results.

\footnotetext{
* Corresponding author: Ayman A Gouda

E-mail address: aymangouda77@gmail.com

Tel: +966542087968

Fax:0020552308213
} 


\section{INTRODUCTION}

Nickel (Ni(II)) is considered to be one of the important hazardous heavy metals used in industry and it is toxic for living organisms at low concentration levels. $\mathrm{Ni}(\mathrm{II})$ was categrized as a carcinogen compund to humans and awide variety of chronic problems related to respiratory tract, lung cancer and skin dermatities were caused by high exposure to $\mathrm{Ni}$ (II) [1]. Therefore, the estimation of trace $\mathrm{Ni}$ (II) in different types of various samples is a very important objective for chemists using effective methods [2,3]. Trace quantities of $\mathrm{Ni}$ (II) in real samples are less than the of detection limit of some instruments like FAAS or GF-AAS and the co-existing ions interference are two limitations in estimations [4,5]. Methods of preconcentration and separation are substantial before the measurements to overcome these limitations by increasing the sensitivity and enhancing estimation accuracy. The development of different methods to separate and enrich of trace $\mathrm{Ni}$ (II) from different samples, such as cloud point extraction [5-11], solid-phase extraction [12-14], co-precipitation [15] liquid-liquid extraction [16-23], and has recently been documented in the literature.

In micelle-mediated extraction methods such as CPE, the extracting phase is homogeneously dispersed (as microdroplets) in aqueous phase, on the other hand for separation of micelles from the aqueous phase at temperatures more than CPT, centrifuging and cooling in unavoidable. Usually, at the last step, adhesion of some parts of the settled extractant (commonly a nonionic surfactant) at the inner layer of the wall of test tube is a common problem, which would affect the accuracy and precision of the determination step. In fact, the analyst encounters a viscose and sticky mass of extractant in the test tube which should be prepared for the analysis step. To overcome this problem, usually a diluting solvent is used to complete the dissolution and then removal of extracting phase from the separator tube. This dilution has a direct influence on the enrichment factor and thus the detection limit and sensitivity of the method. In addition, incomplete separation of traces of aqueous phase from organic phase, and on the other hand, remaining of some traces of this phase in the test tube (as discussed above) at the end of the extraction process could affect the reproducibility of the final results [24].

Analytical chemists have tried to reduce or omit the hazardous toxic and volatile extraction solvents using liquid phase microextraction as a sample enrichment method and ionic liquids (IL) as an extraction phase [19]. The ionic liquids (ILs) were used as environment-friendly solvents because of their excellent physicochemical characteristics like frivolous vapor pressure, economical, green, selective solubility, thermal stabilities and good extractabilities for various organic compounds and metal ions $[25,26]$. Besides these features of ILs, some kinds of them show aggregation behavior in aqueous solutions. This property has introduced them as an alternative to conventional surfactants in various scientific and technological fields [27-29]. The behavior and properties of surface-active ionic liquids (SAILs) in aqueous and nonaqueous solvents have been extensively studied by researchers. For instance, the structural properties of SAILs in oil microemulsion were investigated and methods to adjust the structural parameters of microemulsions using different ionic liquids were reported [30,31].

Surface activity of imidazolium-based ionic liquids with long-chain hydrocarbon groups was considered by some researchers in recent years [32,33]. Like other surfactant molecules, micelle formation of a surface-active ionic liquid (SAIL) occurs at concentrations above a critical value. Measurement of critical micelle concentration (CMC) of imidazolium-based SAILs has been investigated in different ways [34-37]. On the other hand, according to some reports, this property (surface activity) of ILs has been considered as a drawback in IL-based extraction methods. Remaining of some amounts of the extracted analyte species in the aqueous phase by trapping in the aggregated ILs, and thus the incomplete recovery of the analyte, is considered as a major disadvantage of using these kinds of ILs in extraction 
processes $[32,34]$. So, the utilization of SAILCPE method combined with FAAS has some advantages such as simplicity, economic, lower limit of detection, higher preconcentration factor and environment-friendly.

The aim of the proposed study was to develop green, simple and modified SAIL-CPE method in combination with FAAS for preconcentration and accurate determination of trace levels of $\mathrm{Ni}$ (II) ions in real water, food and tobacco samples. In the proposed technique, the micelle formation of the IL phase provides a homogenously dispersed extracting phase; therefore, efficient extraction of the analyte would be possible without the need for dispersion techniques. On the other hand, separation of the extraction phase (ionic liquid micelles) from the aqueous phase is a challenging step in SAIL-based extraction methods. A mixed-micellar system consisting of $\mathrm{C}_{16} \mathrm{MeImCl}$ and Triton-X114 (Figure 1) was used as extracting phase and sunset yellow FCF as complexing agent were selected. The new method has been developed to estimate concentrations of $\mathrm{Ni}$ (II) ions in real water, food and tobbacco samples with satisfactory results.
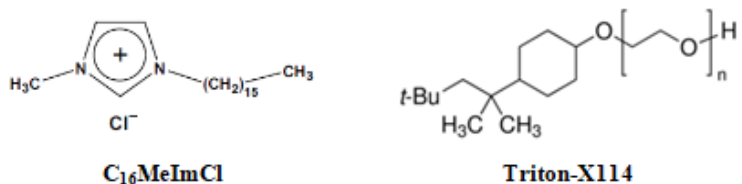

Figure 1. Chemical structure of $\mathrm{C}_{16} \mathrm{MeImCl}$ and Triton-X114.

\section{EXPERIMENTAL}

\section{Apparatus}

Atomic absorption spectrophotometer (Agilent 55 AA; Agilent Technologies Inc., Santa Clara, USA), was utilized to determine the analyte metal. The instrumental conditions were set in accordance with the instructions of manufacturer. Micro injection method was utilized to introduce the sample to the nebulizer of the FAAS. An Adwa AD1000 pH-meter (Szeged, Hungary) was utilized to measure the $\mathrm{pH}$-values of prepared buffer solutions. A centrifuge (Isolab, Germany) was utilized to accelerate the separation of analyte from sample solution. A thermostated water bath with good temperature control was used for the CPE experiments. Milli-Q was utilized to obtain deionized/bidistilled water (Millipore, USA). Glass wares were kept in nitric acid $(5.0 \% \mathrm{v} / \mathrm{v})$ overnight, rinsed and cleaned many times with bidistilled water prior to the experiment.

\section{Reagents and solutions}

All reagents and chemicals used were of high purity and acquired from Merck (Darmstadt, Germany) and Sigma Aldrich (St. Louis, USA) companies. High-quality concentrated $\mathrm{HNO}_{3}(65 \% \mathrm{~m} / \mathrm{m}), \mathrm{HCl}(37 \%$ $\mathrm{v} / \mathrm{v})$ and $\mathrm{NH}_{3}(25 \% \mathrm{v} / \mathrm{v})$ solutions were used. The stock solution of $\mathrm{Ni}$ (II) $\left(1000 \mu \mathrm{g} \mathrm{mL}^{-1}\right)$ was intended from $\mathrm{Ni}\left(\mathrm{NO}_{3}\right)_{2} \cdot 6 \mathrm{H}_{2} \mathrm{O}$ of high purity, (Fluka Chemie AG, Basel, Switzerland). Diluted Ni(II) working solution was obtanied through sequent dilution of the stock standard solution daily. The IL, $\mathrm{C}_{16} \mathrm{MeImCl}$ was purchased from Acros Organics (Geel, Belgium) and the non-ionic surfactant polyethylene glycol tert-octylphenyl ether (Triton X-114) (Sigma-Aldrich, USA) were selected as the extraction solvent. without further purification. Aqueous solution of $\mathrm{C}_{16} \mathrm{MeImCl}\left(0.1 \mathrm{~mol} \mathrm{~L}^{-1}\right)$ was prepared by dissolving the appropriate weight of $\mathrm{C}_{16} \mathrm{MeImCl}$ in $100 \mathrm{~mL}$ of bidistilled water in $100 \mathrm{~mL}$ volumetric flask with stirring. Aqueous $1.0 \%$ (v/v) solution of Triton X-114 was prepared by dissolving $1.0 \mathrm{~mL}$ of Triton $\mathrm{X}-114$ in $100 \mathrm{~mL}$ of bidistilled water in $100 \mathrm{~mL}$ volumetric flask with stirring. A $0.2 \%(\mathrm{w} / \mathrm{v})$ solution of sunset yellow FCF was obtained by dissolving proper weight of sunset yellow FCF (Sigma-Aldrich, St. Louis, MO, USA) in ethanol Sigma Aldrich (St. Louis, USA). The $\mathrm{pH}$ values was adjusted using a series of buffer solutions [38]. The solutions of various cations and anions used for the interference study were obtained from the respective high purity inorganic salts (SigmaAldrich, USA) by proper dilution in bidistilled water. TMDA 51.3 fortified water and TMDA 53.3 fortified water (National Water Research Institute, Environment Canada, Burlington, Canada) and spinach leaves (SRM 1570a) (National Institute of Standard Technology 
(Gaithersburg, MD, USA) were utilized as certified reference materials.

\section{Preconcentration SAIL-CPE procedure}

Aliquots of $40 \mathrm{~mL}$ of the sample solution containing $2.0-600 \mu \mathrm{g} \mathrm{L}^{-1}$ of $\mathrm{Ni}$ (II) were placed in a conical-bottom glass centrifuge tube (50 $\mathrm{mL}$ ) and mixed with $3.0 \mathrm{~mL}$ of phosphate buffer solution ( $\mathrm{pH}$ 6.5). Subsequently, sunset yellow $0.2 \%(\mathrm{w} / \mathrm{v})(1.0 \mathrm{~mL}), 100 \mu \mathrm{L}$ of $\mathrm{C}_{16} \mathrm{MeImCl}$ solution $(0.1 \mathrm{M}), 200 \mu \mathrm{L}$ of Triton-X114 $(1.0 \%$ $\mathrm{v} / \mathrm{v})$, and $1.0 \mathrm{~mL}$ of $\mathrm{NaCl}(2.0 \%, \mathrm{w} / \mathrm{v})$ were added, respectively. The solution was diluted to the mark $(50 \mathrm{~mL})$ with bidistilled water. After that, the tubes were transferred to a water bath for $5.0 \mathrm{~min}$ at $45^{\circ} \mathrm{C}$. To speed up phase separation, the solution was centrifuged at 4000 rpm for $5.0 \mathrm{~min}$. The tubes were taken away and obscure in an ice bath for 5.0 min and cloudy turbid solution was formed. The IL-phase was subsequently sedimented at the bottom of the tube. Using syringe, the upper aqueous phase was rejected. Finally, the remaining IL phase was diluted using acidic methanol to $0.5 \mathrm{~mL}$ and aspirated into the conventional nebulizer of FAAS using microinjection system.

\section{Pretreatment of real samples and CRMs Water Samples}

The proposed procedure was successfully applied to water samples "tap, mineral, sea, and wastewater" acquired from Egypt and stored in polyethylene bottles. All water samples are filtered through a cellulose membrane filter of $0.45-\mu \mathrm{m}$ pore size (Millipore Corporation, Bedford, MA, USA) to eliminate hanging materials before being acidified with diluted $\mathrm{HNO}_{3}$ and stored at $4{ }^{\circ} \mathrm{C}$. To oxidize the organic content of water samples, $\mathrm{H}_{2} \mathrm{O}_{2}(1.0 \% \mathrm{v} / \mathrm{v})$ and $\mathrm{HNO}_{3}(65 \% \mathrm{~m} / \mathrm{m})$ were utilized. The same preconcentration SAIL-CPE technique has been used to the CRM (TMDA-51.3 and TMDA 53.3 fortified water). The $\mathrm{Ni}$ (II) concentrations were evaluated by FAAS.

\section{Food and tobacco samples}

The different vegetables (cabbage, spinach, tomato and potato) and tobacco samples were gained from local markets of Egypt. For 24 hours in an electric oven, the food samples are dried at $80{ }^{\circ} \mathrm{C}$ and homogenized by grinding in an agate mortar. For a wet acid digestion procedure, SRM 1570a spinach leaves, food and tobacco samples $(0.2 \mathrm{~g})$ were treated with 2.0 $\mathrm{mL}$ of a mixture of concentrated $\mathrm{HNO}_{3}-\mathrm{H}_{2} \mathrm{O}_{2}$ $(2: 1, \mathrm{v} / \mathrm{v})$ into beaker and kept at room temperature for $10 \mathrm{~min}$, then heated on an electric hot plate until semi-dried mass was obtained. digested semi-mass samples were dissolved in $10 \mathrm{~mL}$ of deionized water and filtered through a cellulose membrane filter of $0.45-\mu \mathrm{m}$ pore size. Then the developed SAILCPE procedure was satisfactorily applied to the samples.

\section{RESULTS AND DISCUSSION}

\section{Influence of pH}

The $\mathrm{pH}$ has a crucial impact on the extraction yield and the formation of metal-chelate complex [39-41]. Consequently, the influence of $\mathrm{pH}$ on the SAIL-CPE technique of Ni(II)-sunset yellow complex was studied at a $\mathrm{pH}$ range of 3.0-9.0. As illustrated in Figure 2, the extraction efficiency increased with increasing $\mathrm{pH}$ from 3.0-6.0 and maximum quantitative values are accomplished till the $\mathrm{pH}$ rang 6.0-7.0. On the other hand, a miniscule decrease at higher $\mathrm{pH}$ values is obvious. The decrease in extraction of $\mathrm{Ni}$ (II) at $\mathrm{pHs}$ lower than 6.0 might be attributed to the lower affinity of complex formation between $\mathrm{Ni}$ (II) ions and sunset yellow in this $\mathrm{pH}$ range, while the reduction in the absorbance at higher $\mathrm{pH}$ values could be attributed to the hydrolysis of $\mathrm{Ni}$ (II) ions. In subsequent studies, $3.0 \mathrm{~mL}$ of phosphate buffer solution ( $\mathrm{pH}$ 6.5) was chosen. 


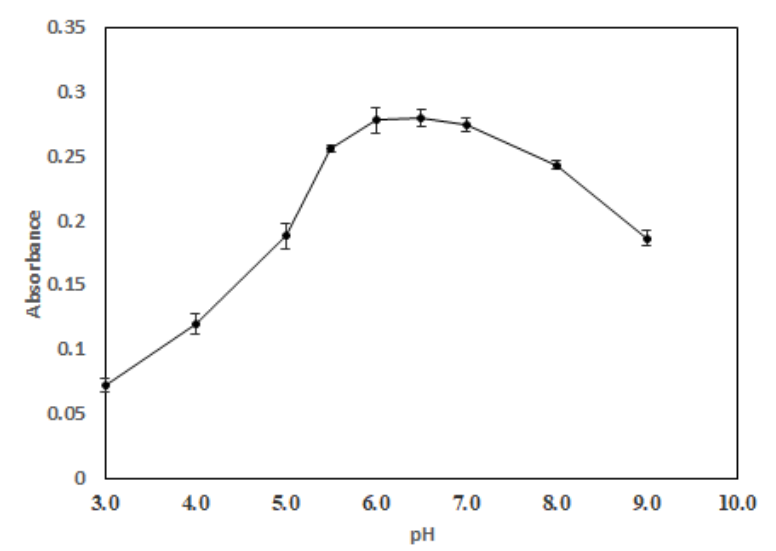

Figure 2. Effect of $\mathrm{pH}$ on the extraction efficiency of $\mathrm{Ni}$ (II) through SAIL-CPE method. Conditions: (Ni(II) concentration, $300 \mu \mathrm{g} \mathrm{L}^{-1}$; concentration of sunset yellow, $0.2 \%(\mathrm{w} / \mathrm{v}) ; \mathrm{C}_{16} \mathrm{MeImCl}(0.1 \mathrm{M})$ volume, $100 \mu \mathrm{L}$; Triton $\mathrm{X}-114(0.5 \% \mathrm{v} / \mathrm{v}), 200 \mu \mathrm{L} ; \mathrm{NaCl}(2.0 \%, \mathrm{w} / \mathrm{v}), 1.0 \mathrm{~mL}$; centrifugation time, $5.0 \mathrm{~min}$; volume of sample, $50 \mathrm{~mL}$ ).

\section{Influence of sunset yellow concentration}

The sunset yellow concentration has important influence on the extraction efficiency of $\mathrm{Ni}$ (II)-sunset yellow complex to give quantitative results. Various concentrations of sunset yellow were examined within the range of $0.05-0.3 \%(\mathrm{w} / \mathrm{v})$ and results curvature is shown in Figure 3. The absorbance has been increased by increasing the sunset yellow concentration up to $0.2 \%(\mathrm{w} / \mathrm{v})$ and higher amounts of sunset yellow have no significant effect in the extraction recovery. Therefore, 1.0 $\mathrm{mL}$ of sunset yellow $(0.2 \% \mathrm{w} / \mathrm{v})$ was utilized as the optimum amount for total complexation and maximum extraction recovery in further studies.

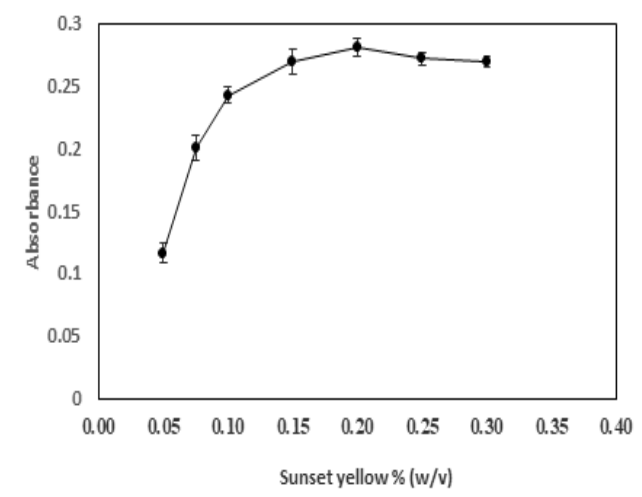

Figure 3. Effect of the sunset yellow concentration on the extraction efficiency of $\mathrm{Ni}(\mathrm{II})$ through SAIL-CPE method. Conditions: (Ni(II) concentration, $300 \mu \mathrm{g} \mathrm{L}^{-1}$; $\mathrm{pH}$ 6.5; $\mathrm{C}_{16} \mathrm{MeImCl}(0.1 \mathrm{M})$ volume, $100 \mu \mathrm{L}$; Triton $\mathrm{X}-114$
$(0.5 \% \quad \mathrm{v} / \mathrm{v}), 200 \mu \mathrm{L} ; \mathrm{NaCl}(2.0 \%, w / \mathrm{v}), 1.0 \mathrm{~mL}$; centrifugation time, $5.0 \mathrm{~min}$; volume of sample, $50 \mathrm{~mL}$ ).

\section{Influence of extracting phase composition}

In the proposed study, choice of type and volume of surfactant was important which has a large influence on the $\mathrm{Ni}(\mathrm{II})$ extraction efficiency. In present work, different non-ionic surfactant (Triton X-114 Triton X-100 and Tween-80) were tested, and the experimental results show that the Triton $\mathrm{X}-114$ was the best one for the extraction of $\mathrm{Ni}(\mathrm{II})$-sunset yellow complex. The variation in extraction efficiency of $\mathrm{Ni}(\mathrm{II})$ within the Triton $\mathrm{X}-114$ concentration range of $0.1-1.0 \% \mathrm{v} / \mathrm{v}$ was examined. The maximum absorbance was observed at $0.5 \% \mathrm{v} / \mathrm{v}$ Triton X-114 (Figure 4). Afterward, the effect of concentration of $\mathrm{C}_{16} \mathrm{MeImCl}$ as SAIL on the extraction efficiency was examined by adding various amounts of $\mathrm{C}_{16} \mathrm{MeImCl}$ from (0.02-0.2 $\mathrm{M})$ to the extraction mixture. According to the obtained results (Figure 5), the maximum extraction efficiency was observed in the presence of $0.1 \mathrm{M} \mathrm{C} \mathrm{C}_{16} \mathrm{MeImCl}$. It should be mentioned that all experiments were conducted in the presence of $(2.0 \% \mathrm{w} / \mathrm{v}) \mathrm{NaCl}$ as saltingout agent.

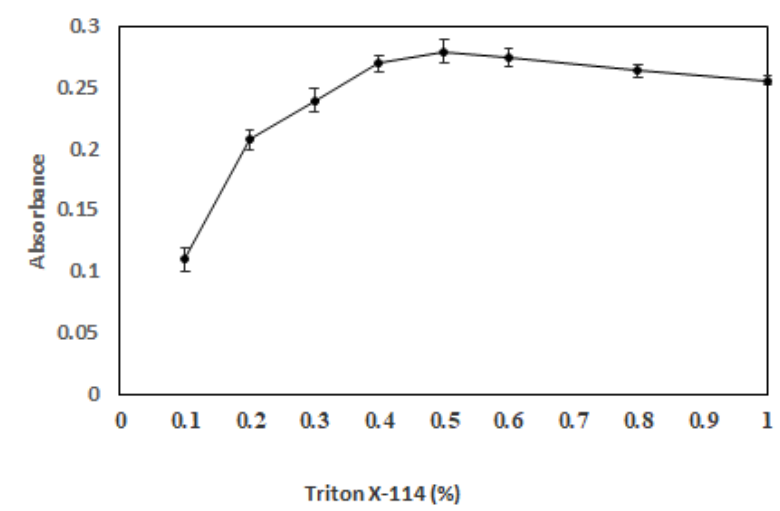

Figure 4. Effect of Triton X-114 concentration on the extraction efficiency of $\mathrm{Ni}(\mathrm{II})$ through SAIL-CPE method. Conditions: (Conditions: (Ni(II) concentration, $300 \mu \mathrm{g} \mathrm{L}^{-1} ; \mathrm{pH} 6.5$; concentration of sunset yellow, $0.2 \%$ $(\mathrm{w} / \mathrm{v}) ; \mathrm{C}_{16} \mathrm{MeImCl}(0.1 \mathrm{M})$ volume, $100 \mu \mathrm{L} ; \mathrm{NaCl}(2.0 \%$, $\mathrm{w} / \mathrm{v}), 1.0 \mathrm{~mL}$; centrifugation time, $5.0 \mathrm{~min}$; volume of sample, $50 \mathrm{~mL}$ ). 


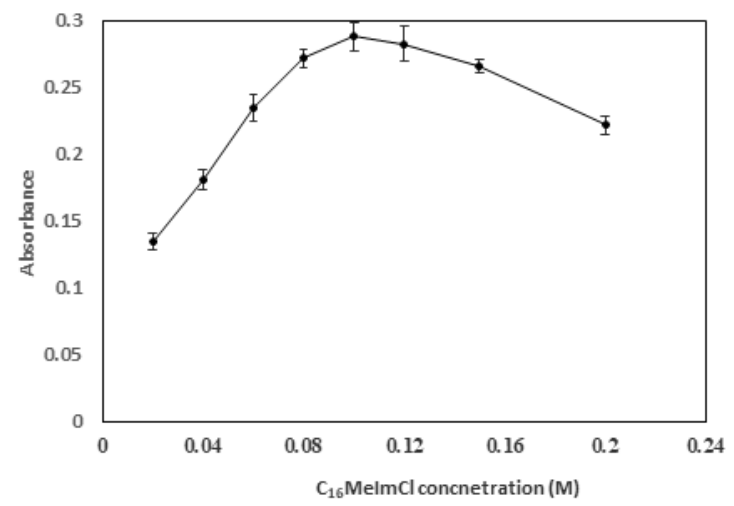

Figure 5. Effect of $\mathrm{C}_{16} \mathrm{MeImCl}$ concentration on the extraction efficiency of $\mathrm{Ni}(\mathrm{II})$ through SAIL-CPE method. Conditions: (Conditions: (Ni(II) concentration, $300 \mu \mathrm{g} \mathrm{L}^{-1}$; $\mathrm{pH} 6.5$; concentration of sunset yellow, $0.2 \%$ $(\mathrm{w} / \mathrm{v}) ; \mathrm{C}_{16} \mathrm{MeImCl}(0.1 \mathrm{M})$ volume, $100 \mu \mathrm{L}$; Triton X-114 $(0.5 \% \quad \mathrm{v} / \mathrm{v}), 200 \mu \mathrm{L} ; \mathrm{NaCl}(2.0 \%$, w/v), $1.0 \mathrm{~mL}$; centrifugation time, $5.0 \mathrm{~min}$; volume of sample, $50 \mathrm{~mL}$ ).

\section{Influence of sample volume}

The Ni(II) solution volume of is an important factor for achieving a high enrichment factor and maximum absorbance based on SAIL-CPE procedure. The sample volume effect was investigated using $(10-100.0 \mathrm{~mL})$ model solutions. Higher than $50 \mathrm{~mL}, \mathrm{Ni}(\mathrm{II})$ ion recoveries were not quantitative. Hence, Ni(II) solution $(50 \mathrm{~mL})$ was chosen as the highest sample volume in all the subsequent studies.

\section{Influence of equilibration temperature and time}

To achieve easy phase separation and efficient preconcentration, it is imperative to optimize the equilibration temperature and time. It was desirable to employ the shortest equilibration time and the lowest possible equilibration temperature, as a compromise between completion of extraction and efficient phase separation. The influence of the equilibration temperature was investigated by varying the temperature from 30 to $70^{\circ} \mathrm{C}$. The results demonstrate that in the temperature at $45^{\circ} \mathrm{C}$, the extraction efficiency for the $\mathrm{Ni}$ (II) sunset yellow complex was constant. Therefore, an equilibration temperature of $45^{\circ} \mathrm{C}$ was chosen for further experiments. Higher temperatures lead to the decomposition of the complex and the reduction of extraction yield. The dependence of extraction efficiency upon incubation time was studied in the range of 1.0 $15 \mathrm{~min}$. An incubation time of $5.0 \mathrm{~min}$ was enough for the separation process and quantitative extraction of analyte.

\section{Influence of centrifugation conditions}

Centrifuge rate and time has important impact on the separation of IL and aqueous phase. The centrifugation rate was tested in the range 1000 and $5000 \mathrm{rpm}$. The centrifugation rate was increased up to $4000 \mathrm{rpm}$ which chosen as the optimum rate for complete separation of extracting phase either in the presence or in the absence of the SAIL. Also, the centrifugation time effect on the analytical signals was evaluated between 2.0 and $20 \mathrm{~min}$. The maximum extraction efficiency was obtained at $5.0 \mathrm{~min}$ to ensure complete phase separation in the presence of SAIL, but 15 min centrifugation was necessary in the absence of SAIL. So, 4000 $\mathrm{rpm}$ and $5.0 \mathrm{~min}$ were chosen as optimum centrifuge rate and time for further studies.

\section{Effects of diluent}

High viscosity of the surfactant-rich phase is drastically decreased using diluting agents. For the spectrophotometric method, the addition of a diluent into the surfactant-rich phase is often needed to obtain a homogeneous solution with compatible viscosity. Methanol, ethanol, acetone, N, N-dimethylformamide, and acetonitrile were tested as diluent solvents. Surfactant-rich phase was found to be freely soluble in methanol. Therefore, acidic methanol was chosen to have appropriate amount of sample for transferring and measurement of the absorbance of the sample and a suitable preconcentration factor. Hence the surfactantrich phase was completed to $0.5 \mathrm{~mL}$ by acidic methanol. Therefore, the preconcentration factor (PF) has been described as the sample volume ratio to the final dilute volume of surfactant-rich phase $(0.5 \mathrm{~mL})$. Therefore, $\mathrm{PF}$ was attained as 100. 


\section{Influence of matrix ions}

The possible effect of the commonly present matrix constituents on the preconcentration and determination of the $\mathrm{Ni}$ (II) ions in different real samples were examined. The results obtained are shown in Table 1. The tolerance limit is defined as the highest amount of interfering ions creating a relative error $\leq \pm 5 \%$. An advantage of this method was that the $\mathrm{Ni}$ (II) ions recovered from the multi-element real samples were quantitative $(>95 \%)$ at the level of tolerance provided in Table 1. No obvious interference effect of matrix ions was observed in the determination of $\mathrm{Ni}$ (II) ions under the experimental conditions which confirm the applicability of SAIL-CPE method for $\mathrm{Ni}$ (II) determination in various real samples.

Table 1. Influence of coexisting matrix ions on the recovery of $\mathrm{Ni}(\mathrm{II})$ ions using the deveolped SAIL-CPE procedure $(\mathrm{N}=3)$.

\begin{tabular}{|c|c|c|c|}
\hline Ion & Added as & 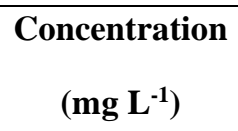 & Recovery (\%) ${ }^{a}$ \\
\hline $\mathrm{Na}^{+}$ & $\mathrm{NaCl}$ & 5000 & $97 \pm 1$ \\
\hline $\mathrm{K}^{+}$ & $\mathrm{KCl}$ & 5000 & $95 \pm 2$ \\
\hline $\mathrm{Ca}^{2+}$ & $\mathrm{CaCl}_{2}$ & 1000 & $96 \pm 3$ \\
\hline $\mathrm{Mg}^{2+}$ & $\mathrm{MgCl}_{2}$ & 1000 & $96 \pm 2$ \\
\hline $\mathrm{Cl}^{-}$ & $\mathrm{KCl}$ & 5000 & $98 \pm 1$ \\
\hline $\mathrm{SO}_{4}{ }^{2-}$ & $\mathrm{Na}_{2} \mathrm{SO}_{4}$ & 2000 & $97 \pm 2$ \\
\hline $\mathrm{NO}_{3}^{-}$ & $\mathrm{NaNO}_{3}$ & 3000 & $96 \pm 3$ \\
\hline $\mathrm{Fe}^{3+}$ & $\mathrm{FeCl}_{3}$ & 500 & $97 \pm 2$ \\
\hline $\mathrm{Mn}^{2+}$ & $\mathrm{MnSO}_{4} \cdot \mathrm{H}_{2} \mathrm{O}$ & 500 & $98 \pm 1$ \\
\hline $\mathrm{Cr}^{3+}$ & $\mathrm{Cr}\left(\mathrm{NO}_{3}\right)_{3} .9 \mathrm{H}_{2} \mathrm{O}$ & 200 & $96 \pm 2$ \\
\hline $\mathrm{Co}^{2+}$ & $\mathrm{Co}\left(\mathrm{NO}_{3}\right)_{2}$ & 50 & $97 \pm 2$ \\
\hline $\mathrm{Cu}^{2+}$ & $\mathrm{Cu}\left(\mathrm{NO}_{3}\right)_{2} \cdot 3 \mathrm{H}_{2} \mathrm{O}$ & 30 & $95 \pm 2$ \\
\hline $\mathrm{Cd}^{2+}$ & $\mathrm{Cd}\left(\mathrm{NO}_{3}\right)_{2} \cdot 6 \mathrm{H}_{2} \mathrm{O}$ & 30 & $96 \pm 2$ \\
\hline $\mathrm{Zn}^{2+}$ & $\mathrm{Zn}\left(\mathrm{NO}_{3}\right)_{2} \cdot 6 \mathrm{H}_{2} \mathrm{O}$ & 50 & $98 \pm 1$ \\
\hline
\end{tabular}

a Mean \pm standard deviation.

\section{Analytical features of the proposed method}

Comparison of the analytical features of the proposed method in the presence and absence of SAIL $\left(\mathrm{C}_{16} \mathrm{MeImCl}\right)$ was made, and the results are featured in Table 2. Using the optimized experimental conditions described above, a satisfactory linear relationship was obtained in the presence of SAIL in the micellar mixture in the concentration range of $2.0-600 \mu \mathrm{g} \mathrm{L} \mathrm{L}^{-1}$ with the following linear regression equation, $\mathrm{A}=5.0$ $\times 10^{-4} \mathrm{C}-2.7 \times 10^{-3}$ with a correlation coefficient $\left(\mathrm{R}^{2}\right.$ 0.9998, $\left.\mathrm{n}=10\right)$, where $\mathrm{A}$ is the absorbance and $\mathrm{C}$ is the $\mathrm{Ni}(\mathrm{II})$ concentration $(\mu \mathrm{g}$ $\left.\mathrm{L}^{-1}\right)$. The limits of detection (LOD) and quantification (LOQ) were calculated as $3 \mathrm{~s}_{\mathrm{b}} / \mathrm{m}$ and $10 \mathrm{~s}_{\mathrm{b}} / \mathrm{m}$, respectively, where $\mathrm{s}_{\mathrm{b}}$ is the standard deviation from ten replicate measurements of blank samples and $\mathrm{m}$ is the 
slope of the calibration curve. The LOD and LOQ were 0.60 and $2.0 \mu \mathrm{g} \mathrm{L}^{-1}$, respectively. The lower detection limit of the present SAILCPE method indicates high sensitivity and suggests its efficient application for the determination of very low concentrations of $\mathrm{Ni}$ (II) in real samples.

The performance of the proposed SAIL-CPE procedure was assessed by calculating two parameters including; the enrichment factor (EF) and the consumptive index (CI). The enrichment factor (EF), defined as the ratio between the calibration graph slopes with and without preconcentration procedure. The consumptive index (CI) was determined using

Table 2. Analytical characteristics of the proposed SAIL-CPE method.

\begin{tabular}{lcc}
\hline Parameters & $\begin{array}{c}\text { In the presence of } \\
\text { SAIL }\end{array}$ & $\begin{array}{c}\text { In the absence of } \\
\text { SAIL }\end{array}$ \\
\hline Calibration range $\left(\mu \mathrm{g} \mathrm{L}^{-1}\right)$ & $2.0-600$ & $10-400$ \\
Calibration equation ${ }^{\mathrm{a}}$ & & \\
Slope $(\mathrm{b})$ & $5.0 \times 10^{-4}$ & $3.0 \times 10^{-4}$ \\
Intercept $(\mathrm{a})$ & $2.7 \times 10^{-3}$ & $1.7 \times 10^{-3}$ \\
Correlation coefficient $\left(R^{2}\right)$ & 0.9998 & 0.9990 \\
$\mathrm{LOD}\left(\mu \mathrm{g} \mathrm{L}^{-1}\right)(3 \sigma, \mathrm{n}=10)$ & 0.60 & 3.0 \\
LOQ $\left(\mu \mathrm{g} \mathrm{L}^{-1}\right)(3 \sigma, \mathrm{n}=10)$ & 2.0 & 10 \\
Relative standard deviation & 1.40 & 2.90 \\
$(\mathrm{RSD} \%$; $=10,300 \mu \mathrm{g} \mathrm{L}-1)$ & & \\
Enrichment factor $(\mathrm{EF})$ & 28.2 & 21.5 \\
Consumptive index $(\mathrm{CI})$ & 1.754 & 2.326 \\
\hline
\end{tabular}

${ }^{\mathrm{a}} \mathrm{A}=\mathrm{a}+\overline{\mathrm{bC}}$, where $\mathrm{C}$ is the concentration of $\mathrm{Ni}(\mathrm{II})$ in $\mu \mathrm{g} \mathrm{L}^{-1}, \mathrm{~A}$ is the absorbance units, $\mathrm{a}$ is the intercept, $\mathrm{b}$ is the slope.

\section{Validation studies}

Additionally, the applicability of the developed SAIL-CPE method was checked and validated for the estimation of $\mathrm{Ni}$ (II) concnetrations in two certified reference materials (TMDA-51.3 fortified water, TMDA53.3 fortified water and spinach leaves SRM 1570a) through standard addition method at the expression $\mathrm{CI}=\mathrm{Vs} / \mathrm{EF}$, where $\mathrm{Vs}$ is the analyte solution volume. The reliability and precision of the proposed SAIL-CPE system as the relative standard deviation (RSD \%) in the presence and absence of SAIL were examined by applying ten replicate determinations of 300 $\mu \mathrm{g} \mathrm{L}^{-1}$ of $\mathrm{Ni}(\mathrm{II})$, and $\mathrm{RSD} \%$ of the recoveries were found to be 1.40 and $2.9 \%$, respectively which illustrate a good precision of the method and confirmed our belief about the effect of $\mathrm{C}_{16} \mathrm{MeImCl}$ on the completeness of separation of extracting phase from the aqueous phase which directly affects the repeatability of the results (Table 2). 
Table 3. The validation of the proposed SAIL-CPE procedure for Ni(II) estimation in CRMs $(\mathrm{N}=3.0)$.

\begin{tabular}{lcccc}
\hline Certified reference materials & $\begin{array}{c}\text { Certified value } \\
\left(\boldsymbol{\mu} \mathbf{~ L}^{-\mathbf{1}}\right)\end{array}$ & $\begin{array}{c}\text { Found } \mathbf{\pm} \mathbf{S D}^{\mathbf{a}} \\
\left(\boldsymbol{\mu \mathbf { g } \mathbf { L } ^ { - \mathbf { 1 } } )}\right.\end{array}$ & $\begin{array}{c}\text { RSD } \\
(\boldsymbol{\%})\end{array}$ & $\begin{array}{c}\text { Recovery } \\
(\boldsymbol{\%})\end{array}$ \\
\hline TMDA-53.3 fortified water & 311 & $303 \pm 0.90$ & 2.50 & 97.43 \\
TMDA-51.3 fortified water & 68.3 & $65.8 \pm 0.80$ & 3.20 & 96.34 \\
NIST 1570a Spinach Leaves & $2.14 \pm 0.1$ & $2.08 \pm 0.06$ & 3.10 & 97.20 \\
\hline
\end{tabular}

${ }^{\mathrm{a}}$ Mean \pm standard deviation based on three replicate determinations.

\section{Analytical applications to real samples}

The potential application of the developed SAIL-CPE preconcentration method to the identify and separate $\mathrm{Ni}(\mathrm{II})$ ion in different real water and acid digested samples including food and tobacco samples was tested. The sample solutions were spiked with known quantities of $\mathrm{Ni}$ (II) ion using the standard addition method to verify the reliability and accuracy of the developed process. Table $\mathbf{4}$ shows the percentage of the analyte recovered from the spiked real sample and the RSD\%. The quantitative recoveries for the $\mathrm{Ni}(\mathrm{II})$ analyte were great, in the range of $95.0-99.50 \%$ with RSD $<3.0 \%$. Such results show that the approach is accurate and could therefore be used in to separate, preconcentrate and evaluate trace amounts of $\mathrm{Ni}(\mathrm{II})$ in real water, food and tobbaco samples.

Table 4. The results for the standard addition-recovery method for the preconcentration of Ni(II) in real samples using the developed SAIL-CPE method $(\mathrm{N}=3.0)$.

\begin{tabular}{|c|c|c|c|c|c|c|c|}
\hline Sample & $\begin{array}{c}\text { Added } \\
\left(\mu \mathrm{g} \mathrm{L^{- }}\right. \\
1)\end{array}$ & $\begin{array}{c}\text { Found }^{a} \pm \\
\text { SD } \\
\left(\mu \mathrm{g} \mathrm{L}^{-1}\right)\end{array}$ & $\begin{array}{c}\text { Recovery } \\
(\%)^{\mathbf{b}}\end{array}$ & Sample & $\begin{array}{c}\text { Added } \\
\left(\mu \mathrm{g} \mathrm{g} \mathrm{g}^{-}\right. \\
1)\end{array}$ & $\begin{array}{c}\text { Found }^{a} \pm \\
\text { SD } \\
\left(\mu g^{-1}\right)\end{array}$ & $\begin{array}{c}\text { Recovery } \\
(\%)^{b}\end{array}$ \\
\hline \multirow[t]{3}{*}{ Tape water } & 0 & $3.28 \pm 0.09$ & - & Cabbage & 0 & $8.50 \pm 0.13$ & - \\
\hline & 100 & $100.40 \pm 0.42$ & 97.21 & & 100 & $107.20 \pm 0.49$ & 98.80 \\
\hline & 200 & $196.0 \pm 0.73$ & 96.42 & & 200 & $198.50 \pm 1.05$ & 95.20 \\
\hline \multirow{3}{*}{$\begin{array}{l}\text { Mineral } \\
\text { water }\end{array}$} & 0 & $<\mathrm{LOD}^{\mathrm{c}}$ & - & Spinach & 0 & $15.0 \pm 0.29$ & - \\
\hline & 100 & $95.60 \pm 0.50$ & 95.60 & & 100 & $112.10 \pm 0.74$ & 97.50 \\
\hline & 200 & $192.0 \pm 1.10$ & 96.0 & & 200 & $213.0 \pm 1.20$ & 99.10 \\
\hline \multirow[t]{3}{*}{ Sea water } & 0 & $40.0 \pm 0.31$ & - & Tomato & 0 & $10.0 \pm 0.23$ & - \\
\hline & 100 & $134.80 \pm 0.96$ & 96.30 & & 100 & $105.80 \pm 0.65$ & 96.20 \\
\hline & 200 & $230.0 \pm 1.30$ & 95.83 & & 200 & $203.70 \pm 0.96$ & 97.0 \\
\hline \multirow[t]{3}{*}{ Well water } & 0 & $<\mathrm{LOD}^{\mathrm{c}}$ & - & Potato & 0 & $6.0 .0 \pm 0.12$ & - \\
\hline & 100 & $99.50 \pm 0.42$ & 99.50 & & 100 & $103.0 \pm 0.54$ & 97.20 \\
\hline & 200 & $194.0 \pm 0.80$ & 97.0 & & 200 & $204.0 \pm 1.35$ & 99.0 \\
\hline \multirow[t]{3}{*}{ Waste water } & 0 & $34.0 \pm 0.28$ & - & Tobacco & 0 & $19.0 \pm 0.23$ & - \\
\hline & 100 & $130.80 \pm 0.50$ & 97.60 & & 100 & $114.0 \pm 0.67$ & 95.80 \\
\hline & 200 & $222.30 \pm 0.97$ & 95.0 & & 200 & $215.50 \pm 1.10$ & 98.40 \\
\hline
\end{tabular}

${ }^{\mathrm{a}}$ Mean \pm standard deviation.

b Recovery\% = [Observed value of $\mathrm{Ni}$ (II) / Expected value of $\mathrm{Ni}(\mathrm{II})] \times 100$

${ }^{\mathrm{c}}$ LOD: limit of detection. 


\section{Comparison with other preconcentration} methods

The proposed SAIL-CPE method was compared to the other extraction procedure documented in the literature [6-8, 12, 15-23]. Comparison allows better analysis, relative to other approaches, of the positive aspects of the proposed method. As can be seen in Table 5, the main advantages of the process were the large working ranges, low detection limits, better reliability (as recovery\%) and repeatability/reproducibility (as RSDs\%) and high PF, as well as the use of green chemicals. According to these properties, using conventional ILs and toxic organic solvents, the SAIL-CPE technique has the potential to be a good alternative to the extraction methods. Such results showed that the proposed SAIL-CPE protocol could be implemented successfully without any systematic error to analyse different real samples.

Table 5. Comparison between the proposed SAIL-CPE procedure and other reported extraction methods for $\mathrm{Ni}(\mathrm{II})$ determination in various samples.

\begin{tabular}{|c|c|c|c|c|c|c|}
\hline $\begin{array}{l}\text { Preconcentration } \\
\text { method }\end{array}$ & $\begin{array}{c}\text { Detection } \\
\text { system }\end{array}$ & $\begin{array}{c}\mathbf{L O D}^{\mathbf{a}} \\
\left(\mu \mathrm{g} \mathrm{L}^{-1}\right)\end{array}$ & $\begin{array}{c}\text { Linearity } \\
\left(\mu \mathrm{g} \mathrm{L}^{-1}\right)\end{array}$ & PF/EF ${ }^{b}$ & Samples matrix & References \\
\hline $\mathrm{CPE}^{\mathrm{c}}$ & FAAS & 5.0 & Up to 80 & 30 & $\begin{array}{c}\text { Peach leaves and } \\
\text { Apple leaves- CRM }\end{array}$ & [6] \\
\hline CPE & FAAS & 1.0 & $10-500$ & 30 & Water samples & [7] \\
\hline $\mathrm{CPE}$ & $\mathrm{SP}$ & 2.0 & $10-250$ & 50 & Water samples & [8] \\
\hline SPE & SP & 3.0 & $10-370$ & - & $\begin{array}{l}\text { Water, food, } \\
\text { biological and soil } \\
\text { samples }\end{array}$ & [12] \\
\hline Coprecipitation & FAAS & 1.05 & $250-5000$ & 25 & Food samples & [15] \\
\hline ILDLLME & SP & 9.8 & $30-1500$ & 200 & $\begin{array}{l}\text { environmental and } \\
\text { biological samples }\end{array}$ & [16] \\
\hline DLLM-SFOD & FAAS & 1.2 & $4.23-250$ & 158 & Water samples & [17] \\
\hline DLLME & FAAS & 1.59 & $10-250$ & 51.8 & $\begin{array}{l}\text { Water samples and } \\
\text { vitamin B12 }\end{array}$ & [18] \\
\hline DLLME & FAAS & 12.5 & $50-500$ & 40.2 & Water samples & [19] \\
\hline DLLME & FAAS & 1.4 & $4.7-100$ & 29 & Water samples & {$[20]$} \\
\hline SSLLME & FAAS & 1.30 & - & 40 & $\begin{array}{l}\text { Water, tobacco and } \\
\text { fertilizer samples }\end{array}$ & [21] \\
\hline EADLLME & GFAAS & 15 & $50-1000$ & 196.4 & $\begin{array}{l}\text { Water and fruit } \\
\text { juice samples }\end{array}$ & {$[22]$} \\
\hline HLLME & GFAAS & 2.2 & $5.0-125$ & - & Aqueous samples & {$[23]$} \\
\hline SAIL-CPE & FAAS & 0.60 & $2.0-600$ & 100 & $\begin{array}{l}\text { Water, food and } \\
\text { tobacco samples }\end{array}$ & $\begin{array}{l}\text { Proposed } \\
\text { work }\end{array}$ \\
\hline
\end{tabular}

${ }^{a}$ LOD: Limit of detection;

${ }^{\mathrm{b}} \mathrm{PF}$ : Preconcentration factor and EF: Enrichment factor.

C CPE: cloud point extraction; SPE: solid phase extraction; ILDLLME: ionic liquid dispersive liquid-liquid microextraction; DLLM-SFOD: dispersive liquid-liquid microextraction based on solidification of floating organic drop; DLLME: dispersive liquid-liquid microextraction; SSLLME: supramolecular solvent liquid-liquid microextraction; EADLLME: effervescence assisted dispersive liquid-liquid microextraction; SAE-DLLME: surfactant assisted emulsification dispersive liquid-liquid microextraction; HLLME: homogeneous liquid-liquid microextraction; FAAS: flame atomic absorption spectrometry; GFAAS: graphite furnace flame atomic absorption spectrometry; SP: spectrophotometry. 


\section{CONCLUSIONS}

In the present study, green, efficient, simple, fast and environmentally friendly mixedmicellar system based on a SAIL-CPE technique was developed and validated to preconcentrate $\mathrm{Ni}$ (II) ions in real water, food and tobacco samples prior to FAAS determination. Good characteristics of the proposed method such as extremely high sensitivity with low LOD $\left(0.60 \mu \mathrm{g} \mathrm{L}^{-1}\right)$, high preconcentration factors (100), simplicity, and green. Moreover, the developed procedure was successfully applied to preconcentrate and determine trace amounts of $\mathrm{Ni}$ (II) ions from real sample solutions without significant interference. Satisfactory repeatability and reproducibility (RSDs\% lower than 3.0\%). The new method was successfully applied to certified reference materials for trace $\mathrm{Ni}$ (II) determination.

\section{REFERENCES}

[1] D. Schaumlöffel, Nickel species: analysis and toxic effects. J. Trace Elem. Med. 26, 1 (2012).

[2] R. Galbeiro, S. Garcia, I. Gaubeur, J. Trace Elem. Med. Bio. 28, 160 (2014).

[3] C. Zeng, X. Xu, N. Zhou, Y. Lin, Spectrochim. Acta A. 94, 48 (2012).

[4] H. Abdolmohammad-Zadeh, E. Ebrahimzadeh, J. Braz. Chem. Soc. 22, 517 (2011).

[5] S.M. Shah, H.N. Wang, X. Su, Chem. Res. Chinese U. 27, 366 (2011).

[6] S.G. Silva, P.V. Oliveira, J.A. Nóbrega, F.R.P. Rocha, Anal. Methods, 1, 68 (2009).

[7] Q. Han, Y. Huo, L. Yang, X. Yang, Y. He, Wu J., Molecules, 23, 2597 (2018). doi:10.3390/molecules23102597.

[8] R. El Sheikh, A.A. Gouda, A.H. Mostafa, N. Salah Eldin, Int. J. Pharm. Pharm. Sci. 7, 176 (2015).

[9] J. Song, W. Zhen, Z. Li, Y. Lian, Y. Yang, Water. Sci. Technol. 66, 792 (2012).

[10] S. Garcia, R. Galbeiro, S.G. Silva, C. Nomura, F.R.P. Rocha, I. Gaubeur, Anal. Methods, 4, 2492 (2012).
[11] Naeemullah, T.G. Kazi, M. Tuzen, J. Ind. Eng. Chem. 35, 93 (2016).

[12] A.S. Amin, A.S. AL-Attas, J. Saudi Chem. Soc. 16, 451 (2012).

[13] H. Ciftci, M.M. Temuz, E. Ciftci, J. AOAC Int., 96, 875 (2013).

[14] M. Tuzen, M. Soylak, D. Citak, H.S. Ferreiara, M.G.A. Korn, M.A. Bezerra, J. Hazard. Mater. 162, 1041 (2009).

[15] D. Citak, M. Tuzen, M Soylak., Food Chem. Toxicol. 47, 2302 (2009).

[16] S.M.N. Moallaa, A.S. Amin, Anal. Methods. 7, 10229 (2015).

[17] Y. Wang, J. Zhang, B. Zhao, X. Du, J. Ma, J. Li, Biol. Trace. Elem. Res. 144, 1381 (2011).

[18] M.H. Sorouraddin, L. Khoshmaram, J. Chin. Chem. Soc. 57, 1346 (2010).

[19] S. Dadfarnia, A.M.H. Shabani, M.S. Bidabadi, A.A. Jafari, J. Hazard. Mater. 173, 534 (2010).

[20] V.A. Lemos, E.V.S. Vieira, E. Santos, L. Santos, CLEAN - Soil Air Water, 40, 268 (2012).

[21] Z.A. ALOthman, M.A. Habila, E. Yilmaz, M. Soylak, S.M. Alfadul, J. Mol. Liq. 221, 773 (2016).

[22] S.M. Sorouraddin, M.A. Farajzadeh, H.N. Qarajeh, Anal. Bioanal. Chem. Res., 6365 (2019).

[23] S.M. Sorouraddin, M.A. Farajzadeh, H. Nasin, Anal. Methods. 11, 1379 (2019).

[24] E.K. Paleologos, D.L. Giokas, M.I. Karayannis, Trends Anal. Chem. 24, 426 (2005) [25] N. Altunay, A. Elik, R. Gurkan, Microchem. J. 147, 277 (2019).

[26] J.A. Barreto, R.S. de Assis, R.J. Cassella, V.A. Lemos, Talanta. 193, 23 (2019).

[27] P. Singla, O. Singh, S. Chabba, R.K.

Mahajan, J. Mol. Liq. 249, 294 (2018)

[28] A. Bera, H. Belhaj, J. Mol. Liq. 224, 177 (2016)

[29] A. Pal, A. Yadav, J. Mol. Liq. 251, 167

(2018)

[30] V.G. Rao, S. Mandal, S. Ghosh, C.

Banerjee, N. Sarkar, J. Phys. Chem. B 117, 1480 (2013)

[31] V.G. Rao, S. Ghosh, C. Ghatak, S. Mandal, U. Brahmachari, N. Sarkar, J. Phys. Chem. B

116, 2850 (2012) 
[32] J. Łuczak, J. Hupka, J. Th»ming, C.

Jungnickel, Colloids Surf. A 329, 125 (2008)

[33] H. Ma, H. Ke, T. Wang, J. Xiao, N. Du, L.

Yu, J. Mol. Liq. 240, 556 (2017)

[34] C. Jungnickel, J. Łuczak, J. Rankeb, J.F.

Fern Undez, A. Müller, J. Thiming, Colloids

Surf. A 316, 278 (2008)

[35] R. Vanyr, L. Biczk, Z. Miskolczy,

Colloids Surf. A 299, 256 (2007)

[36] P.D. Galgano, O.A. El Seoud, J. Colloid

Interface Sci. 345, 1 (2010)

[37] M.A. Rather, G.M. Rather, S.A. Pandit,

S.A. Bhat, M.A. Bhat, Talanta

131, 55 (2015)

[38] H.T.S. Britton, Hydrogen Ions, $4^{\text {th }}$ ed., Chapman and Hall, London, (1952).

[39] A.A. Gouda, Int. J. Environ. Anal. Chem. 94, 1210 (2014).

[40] A.A. Gouda, A.M. Summan, A.H. Amin, RSC Adv. 6, 94048 (2016).

[41] E.M.Hafez, R. El Sheikh, M. Fathalla, A. Sayqal, A.A. Gouda, Microchem. J. 150, 104100 (2019). 